\title{
ROLA UNIWERSYTETÓW W ROZWOJU INNOWACJI - TRZECIA MISJA UCZELNI
}

\section{Abstract \\ The role of universities in the development of innovation - third mission of the university}

The aim of the article is to describe innovation policy and the role of universities in innovation development. Also define what is the third mission of the university, functioning alongside the other two (education and research). The article presents the basic instruments of innovation policy and the ways of technology transfer from science to industry. Methods used in article included the analysis of national and foreign literature as well as analysis of data collected by organizations dealing with innovation policy and R\&D. This article has a theoretical nature.

Keywords: third mission, university, innovation policy, spin-off, collaboration between science and industry

\section{Streszczenie}

Celem artykułu jest opis polityki innowacyjnej oraz roli uniwersytetów w rozwoju innowacji, a także zdefiniowanie, czym jest trzecia - obok edukacji i badań - misja uczelni. W opracowaniu przedstawiono podstawowe instrumenty polityki innowacyjnej oraz ścieżki transferu technologii z nauki do przemysłu. Metody wykorzystane przy tworzeniu tekstu obejmowały analizę literatury krajowej i zagranicznej, a także danych zebranych przez organizacje zajmujące się zagadnieniami polityki innowacyjnej oraz działalności badawczo-rozwojowej. Artykuł ma charakter przeglądowy.

Słowa kluczowe: trzecia misja, uniwersytet, polityka innowacyjna, spin-off, współpraca nauki i przemysłu 


\section{Wprowadzenie}

W niniejszym artykule przedstawiono nową rolę uniwersytetu związaną z realizacją jego tzw. trzeciej misji, obok badań i edukacji. W ramach przygotowań przeprowadzono analizę literatury przedmiotu, danych statystycznych oraz dokumentów strategicznych dotyczących realizacji polityki innowacyjnej, przede wszystkim w krajach Unii Europejskiej oraz w Stanach Zjednoczonych.

Istnieje szereg dokumentów kształtujących politykę innowacyjną na poziomie ponadkrajowym, krajowym i regionalnym. Na poziomie ponadkrajowym są to: Europa 2020, Europejska Agenda Cyfrowa, Unia innowacji, Europa efektywnie korzystająca z zasobów, Polityka przemysłowa w erze globalizacji, Program na rzecz nowych umiejętności i zatrudnienia, Polityka regionalna jako czynnik przyczyniający się do inteligentnego rozwoju w ramach strategii Europa 2020, Program Horyzont 2020 (Horizon 2020) oraz Program COSME.

Raporty na temat dominujących trendów, wskazujące kierunki zmian o zasięgu międzynarodowym, to: Demand-Side Innovation Policies, OECD Innovation Strategy, Next Generation Innovation Policy - the Future of EU Innovation Policy to Support Market Growth, E \&Y, Igniting Innovation, Rethinking the Role of Government in Emerging Europe and Central Asia, WBank oraz raport Esko Aho Creating an Innovation Europe. Europy z kolei dotyczą: Guide to Research and Innovation Strategies for Smart Specialisation (RIS3), Innovation Union Competitiveness Report, Innovation Union Scoreboard 2013, Regional Innovation Scoreboard 2012 oraz European Competitiveness Report 2012.

Dokumenty kształtujące politykę innowacyjną na poziomie krajowym to: Długookresowa Strategia Rozwoju Kraju: Polska 2030. Trzecia fala nowoczesności (DSRK), Raport: Polska 2030. Wyzwania rozwojowe, Narodowa Strategia Spójności (NSS), Krajowy Program Reform (KPR), Strategia Rozwoju Kraju 2020: Aktywne społeczeństwo, konkurencyjna gospodarka i sprawne państwo (SRK) oraz dziewięć zintegrowanych strategii rozwoju, Krajowa Strategia Rozwoju Regionalnego 2010-2020: Regiony, Miasta, Obszary wiejskie (KSRR), Strategia Sprawne Państwo 2020 (SSP), Strategia Innowacyjności i Efektywności Gospodarki „Dynamiczna Polska 2020" (SIEG), Program Rozwoju Przedsiębiorstw (PRP), Policy paper dotyczący rozwoju cyfrowego Polski do 2020 roku, Krajowy Program Badań (KPB), Foresight technologiczny przemysłu - InSight 2030, Polska Mapa Drogowa Infrastruktury Badawczej, Program wspierania inwestycji o istotnym znaczeniu dla gospodarki polskiej na lata 2011-2020, Umowa Partnerstwa (UP), Program Operacyjny Inteligentny Rozwój 2014-2020 (PO IR), Program Operacyjny Polska Cyfrowa 2014-2020 (PO PC), Program Operacyjny Wiedza Edukacja Rozwój 2014-2020 (PO WER), Program Operacyjny Polska Wschodnia (PO PW), Krajowe Ramy Inteligentnych Specjalizacji, Kierunki zwiększania innowacyjności gospodarki na lata 2007-2013 oraz Raporty PARP: Innowacyjność 2010, Innowacyjność 2013.

Na poziomie regionalnym są to Regionalne Strategie Innowacji (RIS), Regionalne Programy Operacyjne (RPO), Strategia rozwoju społeczno-gospodarczego 
Polski Wschodniej do roku 2020, Strategie rozwoju województw (SRW) oraz Strategie innowacyjności miast.

\section{Trzecia misja uczelni}

Według Joanny Machnik-Słomki w historii rozwoju uniwersytetów można wyróżnić jego trzy zasadnicze generacje. Pierwszą z nich jest uniwersytet średniowieczny, którego głównym celem nie było wytwarzanie nowej wiedzy, lecz ochrona i przekazywanie wiedzy z przeszłości oraz nauczanie i przestrzeganie doktryn Kościoła. Uniwersytet Humboldta z kolei skupiał się na badaniach edukacja opierała się na schemacie przyjętym ze średniowiecznych cechów, badania zaś zasadzały się na racjonalizmie i empiryzmie. Uniwersytet trzeciej generacji natomiast ma $\mathrm{w}$ dalszym ciągu zapewniać wysoki poziom kształcenia i badań naukowych, dodatkowo przyjmuje jednak rolę międzynarodowego centrum transferu technologii, które będzie składało się z tradycyjnego uczelnianego ośrodka badawczo-rozwojowego, inkubatorów przedsiębiorczości i innych obiektów dla technostarterów, instytucji finansujących oraz wielu usługodawców branżowych [Machnik-Słomka, 2011].

Obecnie uczelnia musi realizować trzy misje, które obejmują kształcenie, działalność naukowo-badawczą oraz upowszechnianie i popularyzację wyników badań (wdrażanie i komercjalizacja) [Kumaczewski, 2013]. Misja związana z tworzeniem innowacji stanowi jeden z komponentów trójkąta wiedzy (badaniaedukacja - innowacje) [European Intitute of Innovation \& Technology, 2012]. Krzysztof Leja pisze, że w latach osiemdziesiątych XX wieku w Polsce badania aplikacyjne prowadzone $w$ instytucjach akademickich były uważane za nienaukowe; sytuacja ta zmieniła się w ostatnich latach, czego przejawem jest m.in. powstanie w Polsce agencji wykonawczych, takich jak Narodowe Centrum Nauki, finansujące badania podstawowe, i Narodowe Centrum Badań i Rozwoju, powołane do realizacji zadań z zakresu polityki naukowej, naukowo-technicznej i innowacyjnej państwa [Leja, 2015].

Trzecia misja uczelni wiąże się także z odpowiedzialnością za rozwój społeczny i ekonomiczny kraju. Chodzi zatem zarówno o odpowiedź na oczekiwania otoczenia, jak i zdolność do komercjalizacji osiągnięć naukowych. Zdaniem K. Lei efektywność trzeciej misji może być mierzona m.in. za pomocą takich wskaźników jak: przychody badawcze uczelni pochodzące z gospodarki, aktywne umowy o współpracy uczelni z gospodarką, ekspertyzy wykonane dla gospodarki oraz publikacje naukowe dotyczące obszarów zainteresowania gospodarki, a także liczba patentów opracowanych w uczelni, przychody z licencji, firmy typu spin-off, których właścicielem jest uczelnia, ustalone zasady redystrybucji przychodów z komercjalizacji oraz możliwość uzyskiwania stopnia doktora przez osoby z gospodarki (tzw. doktoraty przemysłowe) [Leja, 2015].

Uniwersytety w Polsce mają swój udział we wdrażaniu innowacji dzięki współpracy nauki i biznesu, która odbywa się przez wyposażenie laboratoriów, 
uruchomienie parków technologicznych, centrów badawczych oraz komercjalizację badań (centra innowacji, centra transferu technologii oraz akademickie inkubatory przedsiębiorczości). Celem aktywności akademickich inkubatorów przedsiębiorczości (AIP) jest stworzenie miejsca, gdzie można zacząć swój biznes w sposób możliwie najprostszy i najmniej ryzykowny. W 2009 roku Inkubatory AIP zostały wpisane przez polski rząd na listę projektów kluczowych dla polskiej gospodarki. Działania na rzecz rozwoju innowacji podejmowane są także w klastrach, które tworzą firmy, instytuty badawczo-naukowe, szpitale i fundacje oraz władze lokalne. Zadaniem klastrów jest podnoszenie efektywności wykorzystania zasobów naukowych, komercjalizacja wyników badań naukowych oraz transfer wiedzy do praktyki. Ich działalność opiera się na wspieraniu innowacyjności, nawiązywaniu współpracy, ułatwianiu dostępu do zasobów wiedzy i wspieraniu przedsiębiorczości.

Z najnowszego badania ośrodków innowacyjności Polskiej Agencji Rozwoju Przedsiębiorczości wynika, że w Polsce istnieją 42 parki technologiczne, 23 inkubatory technologiczne, 41 centrów transferu technologii oraz 24 akademickie inkubatory przedsiębiorczości - łącznie jest to 130 instytucji, które odgrywają istotną rolę w procesie dyfuzji technologii oraz wspierania rozwoju innowacyjnej przedsiębiorczości [Bąkowski, Mażewska, 2015].

\section{Definicja polityki innowacyjnej}

Dokumenty kształtujące politykę innowacyjną (strategie, programy, raporty) określają sposoby wspierania innowacyjności gospodarki przez wzmacnianie potencjału nauki oraz współpracę sektora nauki z gospodarką i wsparcie rozwoju społeczeństwa informacyjnego [Portal Innowacji]. Tworzone są one na poziomie ponadnarodowym (np. dla państw UE, dla wspierania gospodarek na poziomie międzynarodowym), jak i krajowym (określające krajowe priorytety) i regionalnym (kształtowanie polityki innowacyjnej na poziomie regionów).

Powszechnie obecnie stosowaną definicją innowacji przy analizach innowacyjności i powiązanych z nią polityk publicznych jest ta zaproponowana przez OECD w trzeciej edycji Podręcznika Oslo [OECD, Eurostat, 2008: 51], gdzie innowacja to wdrożenie w praktyce gospodarczej nowego albo znacząco udoskonalonego produktu, usługi lub procesu, w tym także wdrożenie nowej metody marketingowej lub organizacyjnej redefiniującej sposób pracy lub relacje firmy $\mathrm{z}$ otoczeniem.

Rada ds. Konkurencyjności, działająca przy Radzie UE, we wnioskach ze spotkania, jakie odbyło się w grudniu 2006 roku w Brukseli, wnioskuje, że polityka innowacyjna powinna być rozumiana jak zestaw działań, których celem jest polepszenie dostępu do finansowania innowacji, kreowanie przyjaznego otoczenia regulacyjnego i popytu na innowacje oraz wzmocnienie działań instytucji wspierających proces innowacji, w tym powiązań między sferą nauki a przemysłu [Świstak, Tkaczyński, 2015: 103]. W odnowionej Strategii Lizbońskiej, w której 
zrewidowano część bardzo ambitnych celów przedstawionych we wcześniejszej wersji Strategii Lizbońskiej, utrzymano zakres działań odnoszących się do rozwoju wiedzy i innowacji m.in. poprzez wzrost i poprawę inwestycji w sferze B+R, pobudzenie innowacji, wykorzystanie technik informacyjnych i komunikacyjnych [Świstak, Tkaczyński, 2015: 104].

Innym istotnym dokumentem, w którym przedstawiono zadania polityki innowacyjnej, jest stworzona przez Komisję Europejską Strategia Europa 2020. Strategia na rzecz inteligentnego i zrównoważonego rozwoju sprzyjającego włączeniu społecznemu, a jej kluczowy projekt to „Unia innowacji”. Celem projektu jest wykorzystywanie działalności badawczo-rozwojowej i innowacyjnej do rozwiązywania takich problemów, jak zmiany klimatu, efektywność energetyczna i pod względem zasobów, zdrowie oraz zmiany demograficzne. Konieczne jest wzmocnienie każdego elementu procesu innowacji, począwszy od wstępnych projektów badawczych aż po komercyjne wykorzystanie ich wyników [Komisja Europejska, 2010: 14].

Polityka innowacyjna (innovation policy) definiowana jest w literaturze przedmiotu również jako zestaw elementów polityki naukowej i polityki technologicznej, a jej celem ma być stworzenie właściwego systemu zapewniającego efektywne powiązania pomiędzy nauką, techniką, administracją i rynkiem. W wyniku tych powiązań istnieje możliwość szybkiego wprowadzania innowacji zwiększających konkurencyjność rynku oraz poprawienie jakości życia społeczeństwa [Stawasz, 2011].

W ciągu ostatnich kilku dekad decydenci polityczni zwracali coraz większą uwagę na wpływ innowacji na wyniki ekonomiczne oraz globalne wyzwania. Mimo że polityka innowacyjna jest stosunkowo nowym elementem w programach politycznych, stała się ona z czasem szybko rozwijającym się obszarem polityki publicznej.

Jak pokazuje wykres 1, termin ,polityka innowacyjna” zyskiwał sukcesywnie na popularności od końca lat sześćdziesiątych XX wieku. Początek zainteresowania tym tematem miał związek z powstaniem na uniwersytecie w Sussex Science Policy Research, jednostki zajmującej się badaniami nad innowacjami. Publikacje pracowników naukowych z tej jednostki (m.in. profesora Roya Rothwella) w latach osiemdziesiątych skierowały powszechną uwagę właśnie na politykę innowacyjną. Prawdziwy boom w tym zakresie nastąpił zaś pod koniec lat dziewięćdziesiątych, gdy międzynarodowe organizacje, takie jak OECD, (obok rządów krajowych) zaczęły propagować politykę innowacyjną [Edler, Fagerberg, 2017]. 


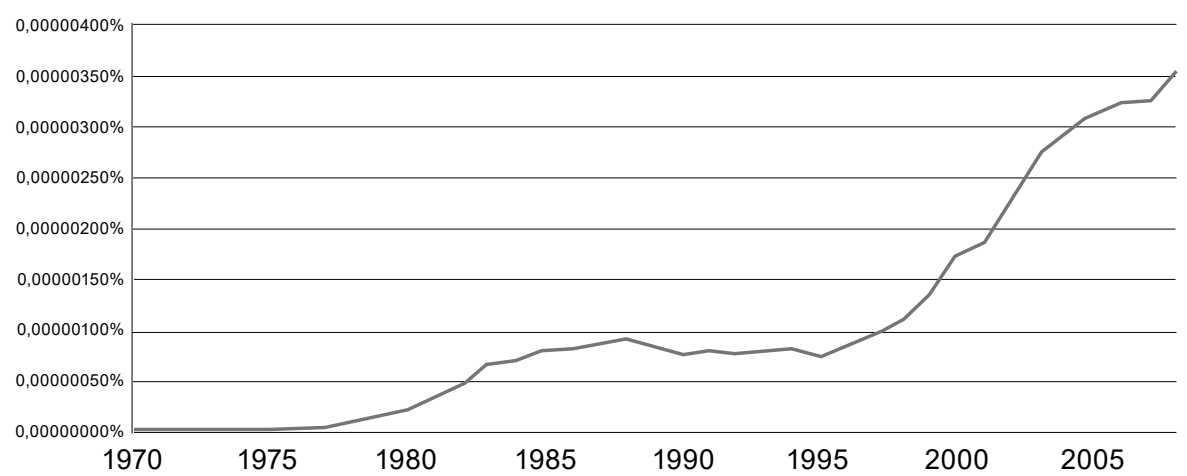

Wykres 1. Częstotliwość występowania terminu ,polityka innowacyjna” według Google

Źródło: opracowanie własne na podstawie Edler, Fagerberg, 2017: 3, oraz Google Books Ngram Viewer.

\section{Instrumenty polityki innowacyjnej}

Polityka innowacyjna składa się z szeregu różnych polityk i instrumentów politycznych. Jakob Edler i Jan Fagerberg [2017] wyróżniają trzy zasadnicze typy instrumentów polityki:

a) odnoszące się do badań podstawowych, dla których odległa jest perspektywa komercjalizacji. W tym wypadku prywatne firmy nie mają zachęty do inwestowania, zatem rola ta spoczywa na państwie, które musi inwestować w publiczne wytwarzanie wiedzy (np. uniwersytety i inne publiczne organizacje badawcze),

b) subsydiowanie badań i rozwoju w prywatnych firmach, co może skłonić przedsiębiorstwa do podjęcia większych nakładów na badania i rozwój,

c) wzmocnienie systemu praw własności intelektualnej ze względu na niepełną ochronę prawną wiedzy i niekompletne prawa własności (IPR).

Instrumenty polityki innowacyjnej w głównej mierze skoncentrowane są na tworzeniu nowej wiedzy i innowacji przez finansowanie badań i rozwoju. Niektóre z nich skupiają się na wspieraniu zdolności i umiejętności generowania i komercjalizacji innowacji, biorąc pod uwagę ciągłą potrzebę uczenia się w systemach innowacyjnych. Pozostałe instrumenty polityczne wspierają różne formy rozwoju innowacji na szczeblu krajowym i regionalnym (w tym klastry). Inna kwestia to podejście decydentów i zainteresowanych stron do tego, aby zrozumieć trendy technologiczne i opracować strategie wspierania ich rozwoju i korzystania z nich [Borrás, Edquist, 2013]. 


\section{Transfer technologii z nauki do przemysłu}

Badania akademickie przyczyniają się do rozwoju innowacji dzięki zastosowaniu różnych ścieżek transferu technologii. Jedną z nich jest patentowanie uniwersyteckie. Rosnąca rola uniwersytetów w rozwoju technologicznym oraz powstanie przedsiębiorczości uniwersyteckiej są najlepiej widoczne, jeśli się weźmie pod uwagę liczbę patentów wygenerowanych przez uniwersytety w ciągu trzech ostatnich dekad, przy czym należy pamiętać, że większość patentów uniwersyteckich posiada tylko kilka instytucji z kilku krajów. Do 50 światowych instytucji zaangażowanych w patentowanie uniwersyteckie należy prawie $40 \%$ wszystkich patentów, a najwięcej takich podmiotów funkcjonuje przy uniwersytetach amerykańskich - aż 33, a europejskich - 7 [Edler, Fagerberg, 2017]. Ograniczona liczba patentów w Europie kontynentalnej w wielu krajach wynika z przepisów dotyczących własności intelektualnej w środowisku akademickim. Niektóre kraje europejskie po 2000 roku zrezygnowały z zasady „przywileju profesora” na rzecz ustawy Bayh-Dole (dotyczącej własności intelektualnej i osiągnięć wynikających z badań finansowanych przez rząd federalny, która pozwala uniwersytetowi, małej firmie lub instytucji non profit na wybranie prawa własności do wynalazku) [35 U.S. Code Chapter 18].

Podstawowymi aktami prawnymi zawierającymi regulację praw własności intelektualnej w Polsce są Ustawa $\mathrm{z}$ dnia 4 lutego 1994 r. o prawie autorskim i prawach pokrewnych oraz Ustawa z dnia 30 czerwca 2000 r. Prawo własności przemysłowej. Wymienione akty prawne zawierają m.in. uregulowania dotyczące ochrony utworów, przedmiotów praw pokrewnych, a także wynalazków, wzorów przemysłowych i użytkowych oraz znaków towarowych. Ochroną mogą być ponadto objęte bazy danych, a także know-how i tajemnice przedsiębiorstw, a podstawę w tym zakresie stanowią przede wszystkim: Ustawa z dnia 27 lipca $2001 \mathrm{r}$. o ochronie baz danych, Ustawa z dnia 16 kwietnia 1993 r. o zwalczaniu nieuczciwej konkurencji, a także Kodeks cywilny. W Polsce obowiązuje też szereg aktów prawnych Unii Europejskiej oraz umów międzynarodowych odnoszących się do ochrony własności intelektualnej [Piechocki, Siciński, 2017].

Europejska polityka innowacyjna ma swoje podstawy prawne w dwóch dokumentach, takich jak: Traktat o Utworzeniu Wspólnoty Europejskiej, tytuł: „Badania i rozwój techniczny" oraz Zielona Księga Innowacji. Traktat o Utworzeniu Wspólnoty Europejskiej ma na celu wzmacnianie bazy naukowej i technologicznej przemysłu Wspólnoty i sprzyjanie jego międzynarodowej konkurencyjności, przy jednoczesnym promowaniu działalności badawczej oraz dążeniu do polepszenia międzynarodowej konkurencyjności krajów Wspólnoty [Traktat o Unii Europejskiej..., 2006]. Zielona Księga Innowacji określa wyzwania, problemy oraz sposoby realizacji Europejskiej Polityki Innowacji. Powstała ona w 1995 roku i była podstawą kreowania Europejskiej Polityki Innowacji w późniejszych latach [European Commission, 1995].

Jednym z instrumentów, które służą transferowi wiedzy i technologii oraz budowaniu przedsiębiorczości akademickiej, są przedsiębiorstwa typu spin-off/spin-out. 
Zdefiniowanie pojęcia „spin-off” jest zadaniem trudnym z tego względu, że w wielu krajach funkcjonuje inne podejście do tego terminu. Różnice odzwierciedlają badania prowadzone przez OECD w kilkunastu krajach [Grela, 2011: 119-121]. I tak jedna z proponowanych definicji firmy spin-off brzmi:

Każda nowa firma, która zatrudnia pracownika sektora publicznego lub uczelni; lub studenta lub absolwenta jako jednego z założycieli; która licencjonuje technologię $\mathrm{z}$ uniwersytetu lub publicznego ośrodka badawczego; [...] rozpoczęła działalność $\mathrm{w}$ inkubatorze lub parku technologicznym powiązanym $\mathrm{z}$ uczelnią lub sektorem publicznym, lub w której uniwersytet lub instytut badawczy dokonał inwestycji [Białek-Jaworska, Gaabryelczyk, 2014: 15].

Swoją definicję opublikował też Portal Funduszy Europejskich. W tym ujęciu spin-off to:

[...] nowe przedsiębiorstwo, które zostało założone przez co najmniej jednego pracownika instytucji naukowej lub badawczej (osoba ze stopniem naukowym co najmniej doktora) albo studenta bądź absolwenta uczelni w celu komercjalizacji innowacyjnych pomysłów (wiedzy) lub technologii, zwykle zależne w pewien sposób (organizacyjnie, formalnie, prawnie, finansowo itp.) od organizacji macierzystej [Portal Funduszy Europejskich].

Istnieje przekonanie, że nowe przedsiębiorstwa oparte na technologii, których kapitał intelektualny pochodzi z uniwersytetów lub innych publicznych organizacji badawczych, przyczynia się do rozwoju innowacji, wzrostu zatrudnienia i przychodów, a także odgrywa istotną rolę w rozwoju klastrów i nowoczesnych technologii [Callan, OECD, 2011]. Niewątpliwie uniwersytety i instytucje badawcze są znacznie bardziej przedsiębiorcze niż kiedyś, jako że znacznie częściej patentują $\mathrm{i}$ licencjonują swoje technologie, inwestują w inkubatory i parki naukowe, a także oferują szkolenia i usługi pomagające wywodzącym się z nich początkującym przedsiębiorcom. Ta orientacja biznesowa jest odpowiedzią na zmiany rynkowe w poszczególnych sektorach, szczególnie w dziedzinie technologii biomedycznych i informacyjnych oraz na konieczność poszukiwania przez laboratoria alternatywnych źródeł finansowania. Spin-offy uosabiają sukces wspomnianego modelu biznesowego wśród instytucji badawczych. Osiągnięcia takich firm, jak Silicon Graphics czy Genentech, pochodzących z Uniwersytetu Stanforda, pozytywnie wpływają na wizerunek uczelni, co pomaga przyciągnąć studentów, a także pozyskiwać kadrę oraz finansowanie.

Jednakże należy pamiętać, że Stany Zjednoczone są niekwestionowanym liderem w tworzeniu spin-offów sektora badawczego (w 1998 roku odnotowano 279 firm typu spin-off z 132 najlepszych amerykańskich uczelni, co daje średnio nieco ponad dwie firmy na uczelnię). Chociaż MIT i Uniwersytet w Cambridge były odpowiedzialne za narodziny tysięcy nowych firm w ciągu ostatnich dziesięcioleci, faktem jest, że większość z nich nie mogła liczyć na bezpośrednie przeniesienie technologii lub wsparcie ze strony instytucji macierzystej. Największą 


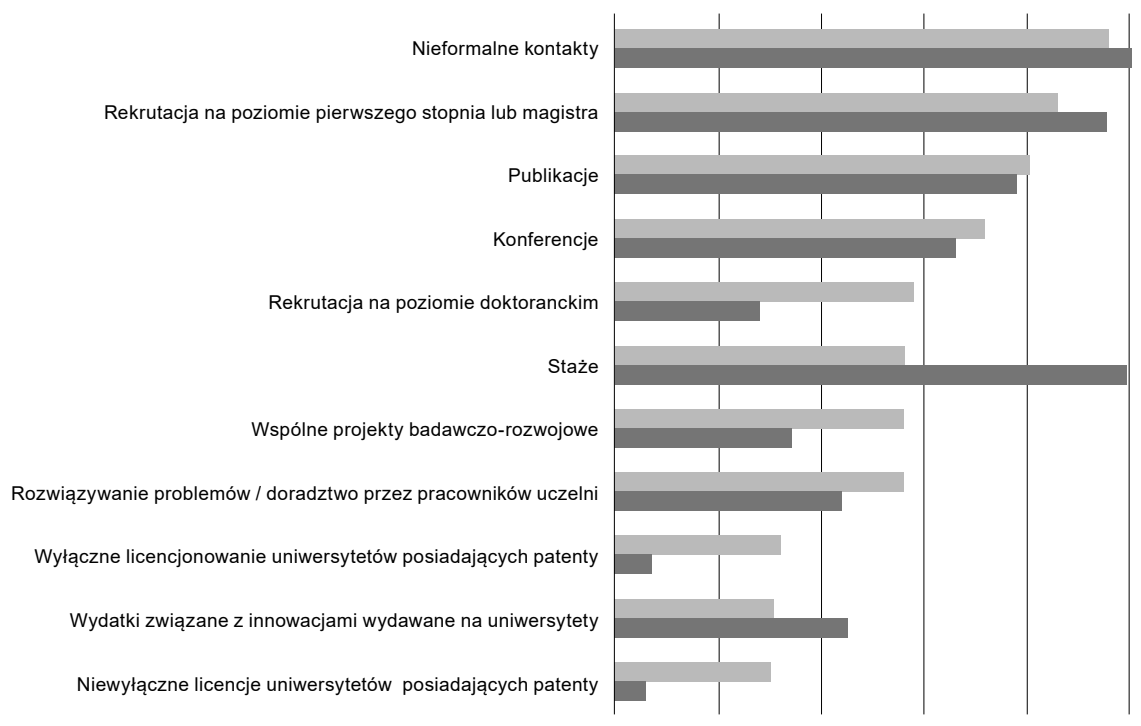

UKロUS

Wykres 2. Typy interakcji pomiędzy uniwersytetem a przemysłem w celu rozwijania działalności innowacyjnej

Źródło: Veugelers, 2016: 624.

liczbę spin-offów poza Stanami Zjednoczonymi wygenerowały Kanada (69 spin-offów z 45 uniwersy tetów w 1998 roku) oraz Wielka Brytania (blisko 4 spin-offy rocznie). Tymczasem większość innych krajów OECD tworzy nie więcej niż kilkadziesiąt takich firm rocznie [Callan, OECD, 2011: 11].

Zmiany w zakresie polityk publicznych wprowadzonych w całej OECD w latach osiemdziesiątych i dziewięćdziesiątych XX wieku znacznie przyspieszyły tempo tworzenia spółek typu spin-off. W wielu krajach przypisano prawo własności intelektualnej do instytucji badawczej, zmieniono przepisy prawa pracy, aby umożliwić badaczom większy kontakt z sektorem prywatnym, zapewniono kapitał zalążkowy na początkowe etapy finansowania, a także zaczęto wspierać rozwój centrów usług, aby pomagać osobom, które chciałyby zainicjować własną działalność biznesową. W pierwszej dekadzie życia spin-offów wielkość, tempo wzrostu i przychody są na ogół skromne. Niewielki odsetek z nich zamienia się w potężne firmy działające w branży wysokich technologii, zatem ich wpływ na rozwój gospodarczy należy badać w szerszym horyzoncie czasowym [Callan, OECD, 2011].

Istnieją także inne ścieżki transferu technologii poza klasycznym modelem. W badaniu przeprowadzonym przez brytyjsko-amerykańskich uczonych zwrócono się z prośbą do firm o wskazanie najważniejszych rodzajów interakcji między 
uczelniami branżowymi, które mają wpływ na rozwój ich działalności innowacyjnej (wykres 2). W obu krajach najważniejsze były kontakty, zaraz po nich rekrutacja na poziomie pierwszego stopnia i magistra oraz dostęp do badań przez publikacje i konferencje. Opatentowanie i licencjonowanie uzyskało najmniej wskazań w odniesieniu do interakcji uniwersyteckich przyczyniających się do rozwoju innowacji. Zatem firmy są bardziej zaangażowane w kontakty z osobami ze świata nauki (przez doradztwo, uczestniczenie w spotkaniach i rozmowach oraz pomoc $\mathrm{w}$ rozwiązywaniu problemów) niż w licencjonowanie i tworzenie spółek typu spin-off.

\section{Główne instrumenty polityki wdrażane w celu poprawy transferu technologii}

W celu zwiększenia wkładu badań naukowych w innowacje i wyniki ekonomiczne wiele krajów wdrożyło różnorodne strategie wzmacniające powiązania pomiędzy uniwersytetami a publicznymi organizacjami badawczymi i przemysłem. Relacje pomiędzy tymi sektorami odzwierciedla model potrójnej helisy (Triple Helix), pozwalający na ukazanie dynamiki powiązań i oddziaływanie w sieci [Leydesdorff, Etzkowitz, 2001].

Model Triple Helix jest nieliniowy i zastępuje modele liniowe systemów innowacji. Ułatwia on analizę nieliniowych interakcji między trzema helisami. Każdy z elementów potrójnej helisy może pełnić funkcję innego, np. ośrodek naukowy może pełnić funkcję gospodarczą, pomagając w powstawaniu nowych firm wyłaniających się z inkubatorów przedsiębiorczości; ośrodek władzy może wspierać nowe przedsiębiorstwa przez programy finansowe czy zmiany w obowiązujących regulacjach prawnych; przemysł może pełnić funkcję ośrodka naukowego w rozwoju, szkoleniu i badaniu często na tak samo wysokim poziomie jak uczelnia [Bojar, Machnik-Słomka, 2014: 100, za: Leydesdorff, Etzkowitz, 2001].

Większość krajów wspólnoty europejskiej posiada systemy wsparcia dla instytucjonalnego transferu technologii. Programy wspomagające klastry, inkubatory, parki naukowe i technologiczne również są bardzo powszechne, ale przy niewielkich alokacjach środków publicznych. Najmniej popularne są systemy wspierania mobilności między środowiskami akademickimi a przemysłem - tylko połowa krajów UE posiada takie systemy, z nieznacznym udziałem funduszy publicznych. Systemy wsparcia dla transferu technologii obejmują także tworzenie Biur Transferu Technologii (BTT), których wspólną podstawową rolą jest wspieranie publicznych organizacji badawczych w zarządzaniu własnościami intelektualnymi w sposób umożliwiający generowanie przez nie korzyści dla społeczeństwa. Rolą BTT jest: nawiązywanie kontaktów z firmami i podmiotami społecznymi; pozyskiwanie nowego wsparcia finansowego w postaci badań sponsorowanych lub działań doradczych; udzielanie pomocy we wszystkich dziedzinach związanych z przedsiębiorczością i własnością intelektualną (IP); ułatwienie powstawania firm powiązanych z uczelniami korzystających z technologii (start-up) i/lub studentów uniwersytetu (spin-off) [OECD, 2011]. 
Jednym z zadań BBT jest patentowanie i licencjonowanie. W kwestiach związanych z patentowaniem należy zwrócić uwagę na to, że proporcja patentów należących do uniwersytetów wzrosła od połowy lat dziewięćdziesiątych w wielu krajach (zwłaszcza w Japonii i niektórych krajach europejskich). W latach 20032005 4\% wszystkich międzynarodowych wniosków patentowych zostało złożonych przez uniwersytety. Rozwój patentów uniwersyteckich był ściśle związany z dynamicznym rozwojem biotechnologii (szczególnie w Belgii, Holandii, Niemczech i Szwajcarii) lub określonej specjalizacji technicznej w danym kraju. W innych krajach patentowanie praw autorskich odbywa się głównie w branży informatycznej i elektronicznej (np. w Korei Południowej), a także w sektorze zdrowia, żywności i energii. W kwestiach związanych z licencjonowaniem tylko kilka BTT negocjuje co roku co najmniej 15 licencji. Trzeba też pamiętać, że więcej licencji otrzymują firmy amerykańskie w porównaniu z europejskimi. Dochody z licencji przeciętnego amerykańskiego uniwersyteckiego biura transferu technologii są zazwyczaj dziesięć razy większe niż w wypadku jego europejskich odpowiedników. Liczba licencji przynoszących dochody również jest większa w Stanach Zjednoczonych niż w Europie.

Wiele europejskich uniwersytetów podążyło za tą tendencją, tworząc własne biura transferu technologii, często ze wsparciem w postaci dotacji publicznych. Wspomaganie transferu technologii jest drugim co do wielkości obszarem programów politycznych służących wzmocnieniu powiązań uniwersytetów i przemysłu w państwach członkowskich UE. Zlokalizowanie w parkach naukowych zapewnia firmom bliższy dostęp do badań akademickich w bardziej nieformalny sposób. Chociaż wiele krajów dysponuje programami publicznymi zakładającymi wsparcie klastrów zaawansowanych technologicznie, budżet przeznaczony na te programy jest marginalny, przynajmniej na szczeblu krajowym [Veugelers, 2016].

\section{Podsumowanie}

Obecnie gdy mowa o innowacyjności, zwykle podkreśla się rolę współtworzenia sieci innowacyjnych (model potrójnej helisy - Triple Helix). Formy te mają ułatwić budowanie połączeń, wzajemne przenikanie się idei i doświadczeń. W zakresie polityki innowacyjnej można wyróżnić kilka zasadniczych dróg prowadzących do powstania sieci innowacyjnych, takich jak patentowanie uniwersyteckie, tworzenie spin-offów oraz te, które znajdują się poza klasycznym modelem (nieformalne kontakty z osobami ze świata nauki, doradztwo, spotkania, realizacja wspólnych projektów, oferta staży dla naukowców/studentów/absolwentów).

Ostatnio mamy do czynienia ze wzrostem liczby patentów akademickich, przy czym jest to zjawisko skoncentrowane w kilku krajach, niewielu instytucjach i obszarach technologicznych. Ponadto, jak można było zauważyć na wykresie 2, przedstawiającym rodzaje relacji przemysłu i nauki, patentowanie i spin-offy niekoniecznie są najważniejszymi środkami transferu technologii, służącymi do ich przekucia na innowacje korporacyjne, większy nacisk kładzie się bowiem na 
nieformalne kontakty między ludźmi, sieci formalne i nieformalne. $Z$ tego względu mobilność studentów i badaczy między środowiskami akademickimi a przemysłem jest kluczowa, zwłaszcza że wiedza naukowa jest dostępna dla przemysłu w trudnych do skodyfikowania kategoriach i często urzeczywistnia się w kapitale ludzkim.

Inicjatywy polityczne mające na celu wsparcie transferu know-how ze świata nauki do przemysłu koncentrują się na klasycznym modelu transferu technologii, naśladując amerykańskie historie sukcesu: wspieranie biur transferu technologii na uniwersytetach lub bardziej ogólnych struktur wspomagających komercyjne badania w dziedzinie patentów, licencji i spin-offów, a także rozwój inkubatorów i parków naukowo-technologicznych [Veugelers, 2016]. Rekomendacją dla decydentów politycznych w zakresie realizowania polityki innowacyjnej mogłoby być unikanie tych działań, które koncentrowałyby się tylko na realizacji trzeciej misji (jak np. patentowanie lub tworzenie spin-off) i zwrócenie większej uwagi na te ścieżki transferu, które obejmowałyby szkolenia i mobilność naukowców (jest to dość mocno zaniedbany kanał transferu technologii). Ta perspektywa systemowa jest szczególnie trudna w procesie kształtowania polityki, ponieważ często kompetencje polityczne różnych misji uniwersytetów rozlokowane są w różnych ministerstwach (edukacja, nauka, innowacje) [Veugelers, 2016].

Inna sugestia wiąże się z tym, że przy obecnym stanie wiedzy politycy powinni bardziej wykraczać poza klasyczne programy transferu technologii, takie jak tworzenie spin-offów i inkubatorów, oraz opracowywać podejście bardziej systemowe, obejmujące wszystkie trzy misje uniwersytetów. Powinni również w większym niż dotychczas stopniu doceniać heterogeniczność wśród uniwersytetów i pielęgnować ich autonomię, aby wypróbować różne modele transferu technologii.

\section{Bibliografia}

35 U.S. Code Chapter 18 - Patent Rights in Inventions Made with Federal Assistance, https:// www.law.cornell.edu/uscode/text/35/part-II/chapter-18 [dostęp: 13.08.2018].

Bąkowski A., Mażewska M. (red.) (2015), Ośrodki Innowacji i Przedsiębiorczości w Polsce. Raport 2014, Polska Agencja Rozwoju Przedsiębiorczości, Poznań-Warszawa.

Białek-Jaworska, A., Gaabryelczyk, R. (2014), Perspektywy rozwoju przedsiębiorczości akademickiej w branży biotechnologicznej, Uniwersytet Warszawski, Warszawa.

Bojar M., Machnik-Słomka J. (2014), Model potrójnej i poczwórnej helisy w budowaniu wspótpracy sieciowej dla rozwoju innowacyjnych projektów regionalnych, „Zeszyty Naukowe Politechniki Śląskiej. Organizacja i Zarządzanie", 76, 99-111.

Borrás S., Edquist Ch. (2013), The Choice of Innovation Policy Instruments, „Technological Forecasting and Social Change", 80(8), 1513-1522.

Edler J., Fagerberg J. (2017), Innovation Policy: What, Why, and How, „Oxford Review of Economic Policy", 33(1), 2-23.

European Commission, (1995), Green Paper on Innovation, Brussels. 
Grela M. (2011), Czym sq firmy typu spin off/spin out? [w:] A.P. Balcerzak, M. Moszyński (red.), Spin off, spin out jako instrument budowania przedsiębiorczości akademickiej oraz stymulowania innowacyjności regionu (s. 119-121), Polskie Towarzystwo Ekonomiczne, Toruń.

Machnik-Słomka J. (2011), Modele biznesowe spółek spin-off w aspekcie komercjalizacji wie$d z y$ [w:] A.P. Balcerzak, M. Moszyński (red.), Spin off, spin out jako instrument budowania przedsiębiorczości akademickiej oraz stymulowania innowacyjności regionu (s. 62-63), Polskie Towarzystwo Ekonomiczne, Toruń.

OECD, Eurostat (2008), Podręcznik Oslo. Pomiar działalności naukowej i technicznej. Zasady gromadzenia i interpretacji danych dotyczacych innowacji, wyd. 3, MNiSW, Warszawa.

Piechocki A., Siciński D. (2017), Zarys ochrony własności intelektualnej w Polsce (Publikacja przygotowana dla Polskiej Agencji Inwestycji i Handlu PAIH), Warszawa.

Stawasz E. (2011), Polityka innowacyjna [w:] K.B. Matusiak (red.), Innowacje i transfer technologii. Słownik pojęć (s. 198-199), Polska Agencja Rozwoju Przedsiębiorczości, Warszawa.

Świstak M., Tkaczyński J.W. (red.) (2015), Wybrane polityki publiczne Unii Europejskiej. Stan i perspektywy, Wydawnictwo Uniwersytetu Jagiellońskiego, Kraków.

Traktat o Unii Europejskiej i Traktat Ustanawiający Wspólnotę Europejską. Wersje Skonsolidowane (2006), Dziennik Urzędowy Unii Europejskiej C 321 E/1, Bruksela.

Veugelers R. (2016), The Embodiment of Knowledge: Universities as Engines of Growth, „Oxford Review of Economic Policy", 32(4), 615-631.

Kumaczewski J. (2013), Misja uczelni-archetyp dobrych praktyk [w:] J. Woźnicki (red.), Misja i stużebność uniwersytetu w XXI wieku (s. 61-67), Warszawa.

\section{Źródła internetowe}

Callan B., OECD (2011), Introduction: The New Spin on Spin-offs, http://www.oecd.org/sti/ sci-tech/introductionthenewspinonspin-offs.htm [dostęp: 14.06.2017].

European Institute of Innovation \& Technology (2012), Catalysing Innovation in the Knowledge Triangle, https:/eit.europa.eu/sites/default/files/EIT_publication_Final.pdf [dostęp: 14.06.2017].

Komisja Europejska (2010), Europa 2020. Strategia na rzecz inteligentnego i zrównoważonego rozwoju sprzyjającego włączeniu społecznemu, Bruksela, http://ec.europa.eu/eu2020/ pdf/1_PL_ACT_part1_v1.pdf [dostęp: 10.06.2017].

Leja K. (2015), Trzy misje uczelni, trzy ścieżki kariery, https://prenumeruj.forumakademickie. $\mathrm{pl} / \mathrm{fa} / 2015 / 01 /$ trzy-misje-uczelni-trzy-sciezki-kariery/ [dostęp: 10.06.2017].

Leydesdorff L., Etzkowitz H. (2001), The Transformation Of University-Industry-Government Relations, „Electronic Journal of Sociology”, file://C:/Users/Admin/AppData/Lo$\mathrm{cal} /$ Temp/th.html [dostęp: 4.12.2017].

OECD (2011), Technology Transfer Offices, http://www.oecd.org/innovation/policyplatform/48136121.pdf [dostęp: 14.06.2017].

Portal Funduszy Europejskich, Spin-off, https://www.funduszeeuropejskie.gov.pl/strony/ slownik/\#Spinoff [dostęp: 14.06.2017].

Portal Innowacji, http://www.pi.gov.pl/Polityka/chapter_95870.asp [dostęp: 11.08.2018]. 